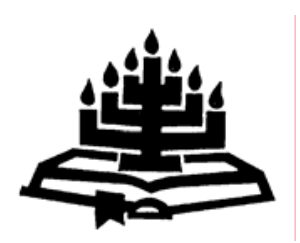

\title{
Basisteoretiese beginsels vir atmosfeer in die erediens afgelei uit 1 Korintiërs 11:17- $14: 40$
}

F.W. Leuschner \& B.J. de Klerk

Skool vir Kerkwetenskappe

Potchefstroomkampus

Noordwes Universiteit

POTCHEFSTROOM

E-pos: wilhelm@gkwapadrant.co.za

Ben.deKlerk@puk.ac.za

\section{Abstract}

Basis-theoretical principles for atmosphere in worship services deduced from 1 Corinthians 11:17-14:40

This article emphasises the central position that the worship service occupies in the life of the believer, but more to the point: the believer as a whole. The atmosphere is therefore vital. This is researched by an exegetical study of 1 Corinthians 1-14. The atmosphere in the worship service should be such that the worshipper meets God with the necessary awe and respect. The service must also create an atmosphere of love, warmth, friendliness and joy. All attenders must be invited and feel welcomed at the service. The atmosphere must further encourage and create room for everybody to participate and use their specific gifts. If the atmosphere in the worship service is adjusted to what it should (and can!) be, the worship service will come closer to its purpose and will become even more of a meeting of the whole person of the believer with the omnipotent God and with every aspect of the fellow believers and the world.

Opsomming

Basisteoretiese beginsels vir atmosfeer in die erediens afgelei uit 1 Korintiërs 11:17-14:40

Die erediens beklee ' $n$ sentrale plek in die lewe van die gelowige as totale mens. Daarom is die atmosfeer in die erediens krities belangrik. Deel 2 ondersoek hierdie belangrike begrip deur 'n eksegetiese studie van 1 Korintiërs 11-14. Die atmosfeer in die erediens moet só wees dat die aanbidder God 
met eerbied en ontsag ontmoet en verder 'n belewenis van liefde, warmte, vriendelikheid en vreugde skep. Al die teenwoordiges moet uitgenooi word en welkom voel. Verder moet die atmosfeer sodanig wees dat almal ruimte kry en aangemoedig word om deel te neem en hulle gawes te gebruik. Indien die atmosfeer in die erediens verstel word na dit wat dit moet (en kan!) wees, sal die erediens nader kom aan sy doel en sal die erediens al meer 'n ontmoeting word van die totale gelowige met die alomteenwoordige God en met die totaliteit van die medegelowiges en die wêreld.

\section{Inleiding}

1 Korintiërs 11-14 handel oor die kerk in aanbidding (Quast, 1994:67) en is daarom van besondere belang vir atmosfeer in die erediens. Wanneer hierdie hoofstukke ondersoek word, word dit duidelik hoedat nie alleen die erediens as geheel nie, maar ook besondere elemente in die erediens ter sprake kom (Du Rand, 1993). Hoewel 1 Korintiërs oor baie meer as net die erediens gaan, handel Paulus meer as een keer regstreeks oor die erediens en word dit algemeen aanvaar dat 1 Korintiërs 11-14 sterk op die erediens toespits (Lloyd-Jones, 1974:8). Dit druis dus nie teen die bedoeling van 1 Korintiërs in om te luister na wat die Woord in hierdie gedeelte oor die erediens spesifiek sê nie (De Klerk, 1987:48).

Die metode wat in hierdie artikel gevolg word, sluit aan by die model wat Zerfass (1974:166 e.v.) vir die Praktiese Teologie ontwerp het. 'n Basisteorie word gevorm deur 'n eksegetiese ondersoek na Paulus se riglyne vir die erediens in 1 Korintiërs 11-14. Daar is in die vorming van 'n Basisteorie meer elemente wat in berekening gebring moet word as net die eksegetiese kant daarvan, byvoorbeeld die teologiese tradisie en die invloed wat dit op die huidige praksis het. Weens die omvang van hierdie artikel is op slegs een aspek (eksegetiese lyne van 1 Kor. 11-14) vir die vorming van 'n basisteorie toegespits.

\section{1 Korintiërs 11:17-34 - onreëlmatighede by die Nagmaal}

In 1 Korintiërs 11-14 hanteer Paulus probleme binne die gemeentelike erediens (Wolmarans, 1999:1512). Uit 1 Korintiërs 11:2-16 kan die volgende afgelei word wat vir die artikel belangrik is: 
- Aanbidding in die erediens, of dit ook al deur 'n man of 'n vrou is, moet tot eer van God geskied.

- In die erediens moet die algemeen aanvaarde samelewingsnorme sover moontlik gehandhaaf word.

- Die erediens is egter nie bloot 'n sosiale byeenkoms nie en daarom moet die Bybelse voorskrifte voorrang geniet.

- Die atmosfeer moet ruimte skep vir deelname ongeag geslag of enige ander onderskeid.

- 'n Erediens is nie 'n onordelike byeenkoms nie.

\subsection{Sake aan die orde in 1 Korintiërs 11:17-34}

In 1 Korintiërs 11:17-34 spreek Paulus sy kommer uit nadat berigte hom hieroor bereik het (1 Kor. 11:18), oor die viering van die Nagmaal in die gemeente van Korinte en die verdeeldheid wat dit veroorsaak. Veral twee sake kom aan die orde: die onderlinge verdeeldheid in die gemeente tydens die Nagmaalviering en die verkeerde motiewe by die gebruik van die Nagmaal.

\subsection{Onderlinge verdeeldheid}

1 Korintiërs 11 gaan nie net om 'n byeenkoms wat "in die gemeente" plaasvind nie, maar om 'n geleentheid waar hulle "as gemeente" saam is, dit wil sê as diegene wat deur die Here uit die wêreld tot redding geroep is en nou in dié hoedanigheid as saamgeroepenes van Christus byeen is (Groenewald, 1967). Paulus kom in 1 Korintiërs 14:23-26 terug op die "saamkom" (s unevcomai) van die gemeente, wat daarop dui dat Paulus in 1 Korintiërs 11-14 hoofsaaklik met die saamkom van die gemeente besig is en dat hy hom telkens toespits op een of ander aspek wat met die saamkom van die gemeente in verband staan (De Klerk, 1987:57).

Kenmerkend van die saamwees as gemeente is hulle eensgesindheid in die diens van God en hulle onderlinge verbondenheid in die liefde. In die vroeë kerk het die gemeentes in die huise van welaf gashere bymekaargekom vir die gemeenskaplike maaltye (Quast, 1994:72). Elke persoon het voedsel en drank saamgebring om dit met mekaar te deel. Gedurende hierdie "liefdesmaaltye" (Judas 12) het die gelowiges die Nagmaal gevier met simboliese woorde en dade. Die hele geleentheid was 'n viering van die eenheid met Christus, en deur Hom, met mekaar. Maar juis hier kom 
die skeuringe in Korinte voor - Paulus noem dit "partyskappe" (1 Kor. 11:19).

Hierdie skeurings is veroorsaak deur die meer welaf lede van die gemeente wat die agapé-maaltyd waarbinne die Nagmaal plaasgevind het, soos 'n private eetpartytjie hanteer het, moontlik soos 'n banket met 'n drinkpartytjie (convivum) daarna (Witherington, 1995:241). In plaas daarvan om vir die minderbevoorregte naaste ruimte te maak aan die gemeenskaplike tafel of 'n bietjie te wag tot almal teenwoordig is (vgl. 1 Kor. 11:33), is daar groepies wat hulle afsonder en haastig hulle eie maaltyd eet (1 Kor. 11:21). Met meer vrye tyd tot hulle beskikking het die rykes vroeër bymekaar gekom as wat die slawe en vrygelatenes, wat langer ure gewerk het, dit kon doen (Quast, 1994:72). So het die maaltyd vir die bevoorregtes in die eetkamer (triclinium) begin voordat die res van die gemeente teenwoordig was. Dié wat laat kom, het met hulle karige bydraes gekom net om die vroegkommers versadig en dronk te vind. Die kerk se viering van die Nagmaal was dus nie meer 'n geleentheid vir herinnering en feesviering nie. In 1 Korintiërs 11:20-21 beklemtoon Paulus dat elkeen sy eie maaltyd eet ("ekasto gar to; ibion deipnon prolambamei ej tw/fagein"). In plaas daarvan dat die Nagmaal ' $n$ eenheidsmaal is waar almal hulle kos met mekaar deel en saam eet, eet elkeen sy eie kos, sonder om iets vir die ander te gee. Die Nagmaal bring gevolglik verdeeldheid in plaas van eenheid.

Omdat die eetkamer (triclinium) van die gemiddelde huis van daardie tyd net plek vir nege tot twintig mense gehad het, het dit daartoe gelei dat daar 'n oorvloei na die binneplein (atrium) was. Die probleem was dat die ryk huiseienaar en gasheer die verdeling op grond van sosiale status gedoen het en dan verskillende kos op verskillende tye aan die verskillende lokale bedien het (Witherington, 1995:29). Dit was dus nie 'n eenheidsmaaltyd van die Here, soos dit bedoel is om te wees nie, maar 'n hele reeks eie maaltye (Lenski, 1963:459). Die gevolg was dat sommige gelowiges niks gekry het om te eet nie, terwyl ander hulle te buite gaan (1 Kor. 11:21). Die sosiale verskille in die gemeente is sodoende oorbeklemtoon en vererger. Op hierdie manier het die saamkom en -eet eerder die gemeente benadeel as opgebou (Postma, 1993). 


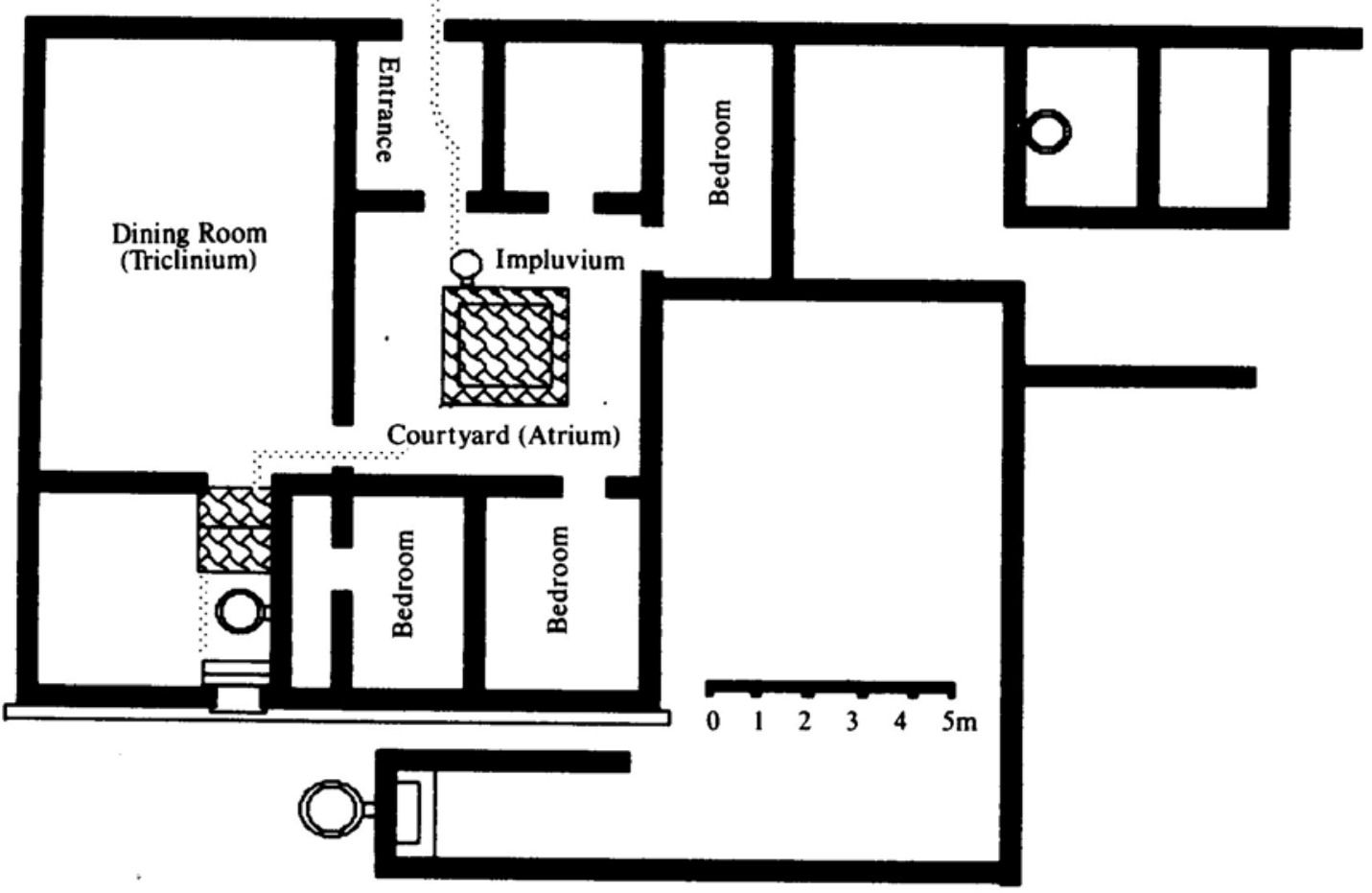

Huis in Korinte

(Quast, 1994:73)

\subsection{Verkeerde motiewe tydens die Nagmaalviering}

As Paulus sê dat niemand die Nagmaal op 'n ongepaste manier mag gebruik nie, verwys hy nie net na diegene wat groepe gevorm het om saam te eet nie, maar ook na gelowiges wat eenvoudig deel daaraan gehad het sonder om oor die volle betekenis van die simbole na te dink (Du Rand, 1993). Paulus stel dit ook dat indien dit vir die lidmate bloot sou gaan om die eet en nie ook om die gemeenskapsbeoefening nie, hulle maar liewer by die huise moes eet (1 Kor. 11:22). Die Nagmaalviering kan ook nie volg op so 'n groepsvorming by die liefdesmaaltyd nie. Die Nagmaal is:

- 'n gemeenskapsmaal waar die gelowige gemeenskap met God en met mekaar beleef;

- 'n herinneringsmaal waardeur die gelowige herinner word aan Jesus Christus se dood en opstanding;

- 'n verkondigingsmaal wat Jesus Christus as Here verkondig aan almal teenwoordig;

- 'n verbondsmaal waardeur die verbond tussen God en die gelowige bevestig word; en 
- 'n verbintenismaal waardeur die gelowige hom of haar tot gemeenskap met God en met mekaar en tot 'n lewe dienooreenkomstig verbind.

\subsection{Gevolgtrekking}

Uit 1 Korintiërs 11:17-34 kan die volgende belangrike afleidings gemaak word:

- Simbole en simboliese handeling speel 'n kardinale rol in die erediens, op voorwaarde dat dit korrek begryp en gebruik word.

- Die verskillende handelinge in die erediens moet verstaan en nie net gedoen word nie.

- Die atmosfeer in die erediens moet uitnodigend, verwelkomend en saambindend wees en nie skeiding en onderskeid bevorder nie.

\section{1 Korintiërs 12:1-11 - een Gees en 'n verskeidenheid van gawes}

\subsection{Inleiding}

1 Korintiërs 12 kan in drie verdeel word: verse 12-27 gaan oor die opbou van die kerk as liggaam van Christus, omraam deur liturgiese riglyne in verse 1-11 en weer in verse 28-31 (vgl. Martin, 1984:5-31). Eers maak Paulus dit duidelik dat die gelowiges se gawes van die Heilige Gees kom en daarom anders is as die "gawes" in die heidense godsdienste (1 Kor. 12:1-3). Hy stel dit ook dat die gemeente ' $n$ eenheid deur die Heilige Gees is (1 Kor. 12:4-6). In vers 7 wys Paulus daarop dat al die charismatiese gawes "tot voordeel van almal" gegee is en gebruik moet word vir die groei van die hele gemeente in gemeenskaplike begrip van God se wil (koinonia) (Martin, 1984:14). In vers 8-10 gee hy dan 'n lys van sodanige gawes. Daardeur word die gelowige in staat gestel om diensbaar te wees binne die gemeente as die liggaam van Christus.

\subsection{Aanbidding deur die Heilige Gees}

Die beoefening van die gawes het aanleiding gegee tot misverstande in die samekoms van die gemeente. Die vraagstuk moet gesien word teen die heidense agtergrond en omgewing van die gemeente (Quast, 1994:79). Van oudsher af het geesdrywery en opsweping van die menslike gees onder die Grieke voorgekom, veral tydens sekere godsdienstige feeste. Die gemeente wat uit 
hierdie heidense tradisie gestam het, het vanselfsprekend ' $n$ hoë waarde geheg aan besondere uitinge van die Gees. Dit het veral voorgekom dat hulle die spreek met tale (glossolalie) hoog geskat het as 'n bewys van die werking van die Gees. Die gevolg was dat wanordelikhede by die erediens voorgekom het.

Vir die gemeente in Korinte was die praat in tale 'n bewys van die werking van die Heilige Gees. Hier wys Paulus hulle daarop dat die kenmerk van die werk van die Heilige Gees die bring tot en uitspreek van die belydenis "Jesus is die Here" (K urio Jhs ou' ) is. In die erediens is die teenwoordigheid en werking van die Heilige Gees deurslaggewend. Hierdie werking lei die aanbidder daartoe om tot ' $n$ belydenisuitroep te kom en daaruit te aanbid: "Jesus is die Here!"

\subsection{Aanbidding deur verskillende gawes}

Daar is ' $n$ verenigde doel in die verskeidenheid van uitdrukkings van die Gees in die lewe van die kerk weens die goddelike oorsprong van elke gelowige se gawe (Soards, 1999:256). Daarom is die verskillende gawes almal gelyk. In die kerk in Korinte is die meer buitensporige gawes, soos praat in tale, verhef en beklemtoon bo ander gawes. Paulus wil hierdie oorbeklemtoning korrigeer deur die gemeente daarop te wys dat al die gawes één oorsprong het (God) en daar is vir slegs een doel, naamlik die opbou van die hele gemeente. Almal is daarom belangrik (Witherington, 1995:257).

In drie verse (1 Kor. 12:4-6) wat parallel loop, wys Paulus op die verskeidenheid werkinge wat almal uitgaan van die één drie-enige God: Vader, Seun en Heilige Gees. Omdat die besondere genadegawes van die Gees aan die orde gestel is, begin hy by die Gees. Daar is ' $n$ verskeidenheid genadegawes, maar hulle gaan almal uit van dieselfde Gees (1 Kor. 12:4). Daar is verder 'n verskeidenheid bedieninge en ' $n$ verskeidenheid werkinge in die gemeente $(1$ Kor. 12:5 en 6). Ook hierdie bedieninge het hulle oorsprong en doel in God en vorm dus 'n eenheid (Witherington, 1995:257). Paulus beklemtoon egter nie net die eenheid nie, maar ook die verskeidenheid.

\subsection{Gevolgtrekking}

Uit 1 Korintiërs 12:1-11 kan die volgende afgelei word:

- Aanbidding moet deur die Heilige Gees wees.

- Die doel van aanbidding is die opbou van almal teenwoordig. 
- Die erediens het ook 'n pastorale dimensie wat deur die atmosfeer ondersteun en uitgebou moet word.

- God gee verskillende gawes waardeur aanbidding tot sy eer en tot opbou van die gemeente moet plaasvind.

\section{1 Korintiërs 12:12-31 - een liggaam met baie lede}

\subsection{Inleiding}

In 1 Korintiërs 12:12-31 bou Paulus verder op die gedagtes van 1 Korintiërs 12:1-11, naamlik dat daar eenheid in verskeidenheid in die gemeente moet wees. Die beeld van die liggaam van Christus dui op die verbondenheid van die kerk aan Christus (1 Kor. 12:27). Die kerk staan met Hom verbonde in 'n korporatiewe eenheid (Roberts, 1988:306). Die Korintiërs is gesamentlik en individueel lede van die liggaam van Christus (Horsley, 1998:173). Die feit dat die lede van die kerk aan mekaar in 'n onderlinge verbondenheid verenig is, word deur hierdie beeld op uitnemende wyse uitgedruk. Die kenmerkende van die liggaam is dat dit 'n organiese eenheid vorm al het dit baie ledemate (Postma, 1993). Paulus neem egter die liggaammetafoor verder as net illustratief - dit word deskriptief: die kerk is die liggaam van Christus (Quast, 1994:80). Die eenheid in Christus word deur die Heilige Gees bewerk en die doop is die seël daarvan. Die eenheid hef egter nie die verskeidenheid op nie, want Jood bly nog Jood en Griek bly nog Griek en almal word deur die Gees gesterk en geregeer (1 Kor. 12:13).

Die verskeidenheid lê in die wyse waarop mense die heil aanvaar en verwerk (Breytenbach \& Pieterse, 1992:104). Die gemeente as liggaam van Christus laat ruimte vir die feit dat daar geen ooreenkoms tussen byvoorbeeld die oog en die voet is nie, maar dat hulle één is in die deelwees aan die liggaam van Christus (1 Kor. 12:21). Die verband van 1 Korintiërs 12:12-14 maak dit duidelik dat die lede wat in die een liggaam ingedoop is, mekaar nodig het, op mekaar aangewese is (Roberts, 1988:310). Die eenheid moet te midde van die verskeidenheid, en die verskeidenheid moet in die eenheid tot harmonieuse lewensuiting in die een liggaam kom. Die liggaam kan funksioneer omdat hy gawes ontvang het en in hierdie sin is elke gemeente van Christus 'n charismatiese gemeente (De Klerk, 1987: 63). Die doel van die charisma lê nie in die mens nie, maar in die nut en voordeel vir die gemeente (1 Kor. 12:7). In vers 25 word dit duidelik gestel dat die lede van die liggaam "gelyke sorg vir mekaar dra". Dit is belangrik om te onthou dat Paulus hier in die besonder 
oor die erediens handel en dat die erediens daarom ook 'n pastorale element van onderlinge sorg moet hê.

Die gemeente as liggaam van Christus skep die ruimte vir 'n bevredigende oplossing van die probleem van die eenheid en verskeidenheid van die kerk. Hierdie probleem het in die laaste dekades ook aktueel geword vir die plaaslike gemeente. Dit hang saam met die verskynsel van pluraliteit (Breytenbach \& Pieterse, 1992:104). Pluraliteit in die gemeente het verdiep vanweë die verskynsel van die moderne groot stad waarin daar hoë beroepsdifferensiasie is en 'n pluriformiteit van idees en perspektiewe op die werklikheid. Die gemeente as liggaam van Christus laat ruimte vir die feit dat daar geen ooreenkoms tussen die oog en die voet is nie, maar dat hulle één is in die deelwees aan die liggaam van Christus met Hom as Hoof (Roberts, 1988:307). Die eenheid in Christus omsluit die pluriformiteit van charismata en insigte, van geaardheid, standpunt en nasionale verskeidenheid. Die eenheid lê in die versoening deur die werk van Christus en nie in die eensgesindheid of in die eendersheid van die gemeentelede nie. Die gemeente as liggaam van Christus kan dus 'n plurale kerk wees binne die konteks van die eenheid en verskeidenheid van die liggaamsbeeld. Die beginsel is dus: die verskeidenheid in die kerk moet die eenheid bevorder; verskeidenheid is nie wesenlik verdelend nie maar verenigend; verskeidenheid en eenheid kompeteer nie en hoef nie uitgebalanseer te word nie, maar hulle bevorder mekaar oor en weer (Berkhof, 1973:419, 425).

Ons moet egter in gedagte hou dat die "liggaam van Christus"metafoor nie losgemaak mag word van die "Hoof-liggaam"-beeld nie. Christus is as Hoof die oorsprong en doel van die kerk - nie net van die universele kerk nie, maar ook van elke plaaslike kerk. Christus is nie die hoogste Hoof van die kerk nie, maar die enigste Hoof (Du Plooy, 1998:5). Die metafoor "liggaam van Christus" belig die noodsaak van die Christusregering in die kerk en die sigbare gemeenskap van die gelowiges as kenmerke van die kerk. Die kerk kan daarom nie anders as om die Christusregering en liefdesgemeenskap van die gelowiges in enige gegewe omstandigheid te kontekstualiseer nie. Die lewegewende Gees van die Vader en die Seun verbind die lede van die liggaam met die naelstringgawe van die liefde aan mekaar (Nel, 1994:228). Dit beteken juis dat gelowiges nie los van mekaar en sonder mekaar kan en wil bestaan nie. Hulle deel inderdaad die lewe wat in Christus en deur die Heilige Gees meegedeel is. Soos enige lewende organisme moet 
die kerk (en die gemeente) ook groei, groei in grootte, maar ook groei in volwassenheid.

\subsection{Gevolgtrekking}

Uit 1 Korintiërs 12:12-31 kan die volgende afgelei word:

- Die kerk is nie bloot 'n sosiale bymekaarkoms nie, maar is die liggaam van Christus. Ook in die erediens moet hierdie organiese band met Jesus Christus sterk na vore kom. Christus bepaal dus in 'n sekere sin die atmosfeer, omdat alles uit die Hoof kom, in die kragveld van die Hoof geskied en tot die Hoof gerig is.

- Die kerk is 'n eenheid deur die Heilige Gees - 'n eenheid wat ook in die erediens ervaar moet word en deur die erediens gebou moet word. Daarom moet die atmosfeer sodanig wees dat dit mense saambind, intrek, verwelkom en tuis laat voel.

- Tog is die kerk ook 'n verskeidenheid. Elkeen het gawes gekry om in die erediens te gebruik tot voordeel van die hele gemeente. Daarom moet daar ook 'n atmosfeer heers wat die uitlewing van gawes ondersteun en aanmoedig. Dit moet sodanig gebeur dat die gawes as gawes van God herken en erken word en nie in mensbewondering ontaard nie.

- Omdat almal verskillende gawes ontvang het, moet die gelowiges mekaar verdra en vir mekaar ruimte gun sodat elkeen God met sy eie unieke gawes kan dien.

- Hoewel sekere lede meer prominent is, maak hulle prominensie hulle nie belangriker as die ander lede nie. Prominent is nie gelyk aan belangrik nie. Almal is belangrik en dit moet ook in die erediens na vore kom.

- Elkeen in die kerk moet gelyke sorg vir mekaar dra. Die atmosfeer moet hierdie sterk pastorale fokus moontlik maak en fasiliteer.

\section{1 Korintiërs 13 - die liefde}

In hierdie hoofstuk verduidelik Paulus wat ware liefde as die "grootste gawe" eintlik beteken en in hoofstuk 14 hoe die liefde prakties toegepas moet word. Die Korintiërs het sommige geestesgawes belangriker as ander beskou en in hulle hoogmoed daarna gestrewe om aansien te bekom, deur die sogenaamde belangrike gawes te beoefen. Paulus wys hulle ' $n$ ander pad wat bewandel moet word, naamlik die beoefening van die liefde. Hierdie liefde is nie gewone 
menslike liefde nie, maar die Christelike liefde wat deur die Heilige Gees in die harte van gelowiges gegee word (vgl. Rom. 5:5). Om dié lied reg te verstaan, moet dit steeds gesien word teen die agtergrond van die beoefening van die gawes in Korinte. Wat merkwaardig is, is dat Paulus in die middel van sy bespreking van die erediens 'n hoofstuk oor die liefde invoeg (Soards, 1999:271). Dit dui op die noodsaak en belang van die liefde in die erediens. Paulus verander ook sy skryfstyl en hierdie hoofstuk is in liriese taal geskryf (Thistelton, 2000:1027), in teenstelling met die prosaïese taal van die brief tot dusver. Omdat Paulus steeds met die erediens besig is, kan afgelei word dat die erediens ook 'n liriese, digterlike kant het. Die liefde is nie maar net een van baie gawes nie, of selfs die beste van al die gawes nie (Witherington, 1995:266), maar 'n lewenswyse (Carson, 1987:56).

Sonder die liefde is daar geen verskil tussen die praat in tale en profesieë wat so algemeen in heidense tempels was (bv. in die kultus van Cybele) en die doen daarvan in Christelike eredienste nie (Witherington, 1995:267). Die wese van ware spiritualiteit is vir Paulus selfopofferende liefde en nie gawes, kennis of bonatuurlike krag nie. Die eienskappe van die liefde is belangrike aanwysers vir die atmosfeer in die erediens. Dit is belangrik dat die atmosfeer vriendelik, geduldig en vreugdevol moet wees uit liefde en as gevolg van die werklikheid van God se liefde. Daar moet altyd in die erediens gewaak word teen afguns, verwaandheid, selfsug en selfgesentreerdheid in die erediens, omdat dit die atmosfeer van liefde sal skaad.

Paulus verklaar liefde verder deur te wys op die tydelike kwaliteit van die gawes teenoor die durende, ewige kwaliteit van die liefde (Soards, 1999:274). Paulus wys daarop dat die kennis, profesie en talespraak sal ophou, omdat dit nog gedeeltelik (1 Kor. 13:8-9) is, terwyl dit wat volmaak is, die liefde, vir ewig sal voortbestaan. Vir die erediens is dit besonder belangrik om te beleef dat die kerk, die gelowiges en die erediens die produk is van God se volmaakte liefde wat $\mathrm{Hy}$ in sy Seun aan die kruis getoon het. Daarom moet die aanbidders hierdie liefde beleef en ervaar, maar dit ook uitleef en aan mekaar betoon. Die erediens moet gekenmerk word deur liefde. Die wese van die erediens is liefde - die liefde van God wat uitvloei in die liefde van die aanbidders teenoor Hom en teenoor mekaar. 


\subsection{Gevolgtrekking}

Uit 1 Korintiërs 13 kan die volgende afgelei word:

- Die liefde moet sentraal staan in die erediens. Sonder liefde is alle dinge waardeloos. Alles in die erediens moet dus uit liefde, in liefde en met liefde gedoen word. 'n Atmosfeer van selfopofferende liefde moet alles in die erediens deursuur.

- Liefde vind in die erediens gestalte in vriendelikheid, geduld en vreugde oor die waarheid.

- Die erediens is nie net 'n rasionele byeenkoms nie, maar moet ook ruimte skep vir die liriese en poëtiese, die ervaring.

- Selfsug, selfgesentreerdheid, verwaandheid en liggeraaktheid beïnvloed die atmosfeer negatief.

- Omdat kennis en profesie nog ten dele is, mag daar nie geredeneer word dat die volmaakte vorm van erediens vasgestel en afgeforseer kan word nie.

\section{1 Korintiërs 14:1-25 - praat in tale in die erediens}

In hoofstuk 12 het die apostel oor die genadegawes in die algemeen gepraat, met nadruk op die eenheid en die verskeidenheid. Hoofstuk 13 besing die uitnemendheid van die liefde en stel al die ander gawes daaraan ondergeskik. In hoofstuk 14 is Paulus nog steeds besig met die kerk wat vir die beoefening van die godsdiens in die openbare erediens saamgekom het (De Klerk, 1987:68). 1 Korintiërs 14:1-12 handel veral oor die teenstelling tussen praat in tale en profesie; in verse 13-19 word die teenstelling tussen bid en praat in tale gemaak; en in verse 20-25 gaan dit om die betekenis van die erediens vir die nie-gelowige.

In vers 1-12 wys Paulus daarop dat profesie die een gawe is waarvoor almal in die gemeente hulle moet beywer (1 Kor. 14:1, 5), want juis deur die gawe van die profesie word die gemeente opgebou (1 Kor. 14:1, 12, 24). Profesie is die gawe om die lig van God se Woord op 'n bepaalde konkrete situasie te werp, om die gemeente te vermaan, te bemoedig en te leer (De Klerk, 1987:69). Paulus kontrasteer profesie en praat in tale en wys op twee kardinale verskille: profesie is verstaanbaar en bou die gemeente op, terwyl praat in tale onverstaanbaar is en net die een wat praat word opgebou. Profesie bou juis op omdat dit op ander aanbidders gerig is en verstaanbaar en ordelik is. Deur daarop te wys dat profesie opbou, bemoedig en vertroos (1 Kor. 14:3) beklemtoon 
Paulus die pastorale dimensie van profesie, en deur profesie, van die erediens. Die erediens is nie net daar om intellektueel te stimuleer nie, maar ook om pastorale ondersteuning te bied deur opbou, bemoediging en vertroosting.

1 Korintiërs 14:13-19 handel oor die teenstelling tussen bid en praat in tale. Onder beheer van die Gees is die ware karakter van die erediens in sy korporatiewe aard geleë. Die gebed word juis daarom aan die groei en verryking van die hele liggaam gekoppel (1 Kor. 14:17). Vanaf 1 Korintiërs 14:14 maak Paulus onderskeid tussen sy "gees" (wat nie rasioneel is nie) en sy "verstand" (wat rasioneel is en die sentrum is van denke en oordeel) (Witherington, 1995:283). Hy roep die Korintiërs op om met die gees sowel as die verstand te bid. Paulus maak in hierdie gedeelte gebruik van begrippe wat saam die volle omvang van danksegging weergee: hy onderskei tussen bid en psalmsing en vat die twee saam as lofprys. Die gebed, psalm en lofprysing van die gemeente in die erediens het 'n onderrigtende karakter (Ef. 5:18 e.v.; Kol. 3:16) en in 1 Korintiërs 14:17 word die onderrigtende karakter beskryf as geestelike opbou. Sang is 'n besonder direkte en kragtige wyse van kommunikasie tussen die gemeente en Christus (Barnard, 1980:24). Juis daarom is dit die Gees wat die gemeente in die sing van die lied beheer en Hy gee ook aan die gelowiges die gawe om 'n psalm te besit (1 Kor. 14:26). Die lied het 'n eie plek in die erediens en is nie bloot ' $n$ reaksie op of voorbereiding tot 'n ander handeling nie. Die voorwaarde vir opbouende, onderrigtende, inspirerende en betekenisvolle sang is dat die gemeente 'n Geesvervulde gemeente moet wees (De Klerk, 1987:71).

Dit is belangrik dat 'n "gewone mens" die woorde van die gebed en die liedere sal verstaan, sodat hy dit kan toeëien, daardeur aangeraak kan word en daarop "Amen" kan sê (1 Kor. 14:16). Die woord amen beteken: dit staan vas, dit is waarheid, of ook as bede: mag dit vas bly staan. Deur die amen uit te spreek, word instemming betuig met wat ' $n$ ander sê. Dit kom veral voor as bevestiging van die gebed of van die lofuitspraak (vlg. 1 Kron. 16:36; Neh. 5:13; 8:6 e.v.; Ps. 41:14; Openb. 1:6). Deur die uitspreek van die amen het die gemeentelid deelgeneem aan die erediens en hom vereenselwig met wat gespreek, gebid en gesing is (Carson, 1987:106)

Die openbare erediens dien vir die gemeente tot opbou en tot voordeel. Hierdie erediens kan selfs vir nie-gelowiges 'n groot voordeel inhou en Paulus beskryf dit in 1 Korintiërs 14:20-25. Ook hier word die "praat in tale" teenoor die profesie gestel en dan veral die verskillende reaksies wat ongelowiges (a $p$ is $t$ $0 \sim$ ) en onvolwasse 
gelowiges (i ji wth $\sim$ ) daarop sal hê. Op 'n erediens, vol van vreemde tale, sal die ongelowige se reaksie wees dat die gemeente van hulle verstand af is (mainoma i - om irrasioneel te dink, om mal te wees, waansinnig; Louw \& Nida, 1989). Hieruit blyk dat die "onkundiges of ongelowiges" in hierdie geval nie tot die gemeente behoort nie, soos wel blyk in 1 Korintiërs 14:22, maar nog tot die Here gelei moet word (1 Kor. 14:25). Dit is persone wat by geleentheid 'n samekoms van die gemeente bywoon, of uit nuuskierigheid binnekom terwyl die gemeente "op een plek" (vgl. 1 Kor. 11:20), dit wil sê vir 'n erediens, byeen is. As "almal" (wat daartoe die gawe ontvang het) deurmekaar in tale praat, sal so 'n buitestander noodwendig die indruk kry dat hulle kranksinnig is (vgl. Hand. 2:13) en teleurgesteld weggaan.

Paulus skryf dat 'n buitestander God moet ontmoet, wat daarop dui dat 'n erediens selfs vir 'n buitestander iets van God moet wys. Teenoor die vraag van die buitestander wat die vreemde tale hoor: "Is hulle van hulle verstand af?" toon Paulus in 'n stygende lyn die uitwerking aan wat die profeteer in 'n verstaanbare taal van die hele gemeente op die buitestander het:

- hy word in sy gewete aangespreek;

- hy kom tot selfondersoek;

- die verborge dinge van sy hart kom aan die lig;

- hy val op sy knieë;

- hy aanbid God;

- hy getuig openlik: "Waarlik, God is hier by julle!" (1 Kor. 14:2425).

Wanneer die Woord van God (deur die profetiese woorde en uitlewing van die gemeente) tot 'n ongelowige kom, het dit deur die werking van die Heilige Gees twee gevolge (vgl. Soards, 1999:294):

1. Die ongelowige word ontbloot van alle voorwendsels en skandes (die verborge dinge van sy hart kom aan die lig); en

2. Die ongelowige kom daartoe om God te aanbid en in die erediens te ervaar.

Hier word die essensie van die ware erediens, van ware aanbidding aangegee: "Waarlik, God is hier by julle." 'n Erediens kan 'n kragtige effek hê op ongelowiges, omdat dit bonatuurlik en verstaanbaar is (Witherington, 1995:285). Die apostel bring 'n verdere oorweging of 
beginsel vir die erediens en die gebruik van gawes in die erediens in berekening. Hy wil dat die gedrag van die gemeente by sy samekoms sodanig moet wees dat dit die buitestander aanlok en nie afstoot nie, met ander woorde die gemeente moet steeds rekening hou met die nie-Christene, omdat hy altyd 'n missionêre taak het, selfs wanneer hy nie daarvan bewus is nie. Die woorde van só 'n ongelowige gee die essensie van die ware erediens weer "Waarlik, God is hier by julle" (vgl. De Klerk, 1987:73). Hierdie woorde is 'n aanhaling uit Jesaja 45:14 (vgl. Sef. 8:23). Deur sy profeet, sê God dat die Egiptenare sal kom en voor die volk sal "buig" en sal bely "Waarlik, God is by jou". Die eienskap van 'n ware erediens is die teenwoordigheid van God en die belewenis daarvan deur die aanbidders. Die groot gevaar in die erediens is juis dat die menslike gawes voorop gestel en bewonder word, sonder dat God se teenwoordigheid duidelik begryp en beleef word. Die wese van die

erediens is 'n byeenkoms in God se teenwoordigheid. In die erediens is dit kardinaal dat elke aanbidder ontbloot voor die almagtige God verskyn en tot ware aanbidding kom - 'n aanbidding wat uitloop in die belydenis "Waarlik, God is hier!"

\subsection{Gevolgtrekking}

Uit 1 Korintiërs 14:1-25 kan die volgende afgelei word:

- Die erediens het die opbou van die gemeente ten doel en daarom moet die gawes wat die opbou van die gemeente dien, nagestreef word - veral die gawe van profesie.

- Die opbou het 'n besliste pastorale dimensie wat deur die atmosfeer aangehelp moet word.

- Dit is belangrik dat dít wat in die erediens gebeur verstaanbaar is, sodat dit die gemeente kan opbou. Dit beteken dat die hele gemeente dit moet verstaan. Hierdie verstaanbaarheid sien nie net op die taal wat gebruik word nie, maar ook op die gebeure self, sodat elkeen teenwoordig op dit wat hy hoor én dit wat hy sien kan "Amen" sê.

- Dit bring ook mee dat dit tot die wese van die erediens behoort dat elke persoon moet kan deelneem aan al die handelinge binne die erediens

- Hoewel die opbou van die gemeente in die erediens voorop staan, moet die erediens sensitief wees vir buitestanders en ongelowiges. Die atmosfeer moet sodanig wees dat dit buitestanders en ongelowiges uitnooi om in te kom, dat hulle tuisvoel 
as hulle eers in is en dat hulle God tydens die erediens ontmoet, sodat hulle in hulle harte aangeraak sal wees. Daarom is dit belangrik dat niks moet gebeur wat buitestanders en ongelowiges intimideer of wegdryf van die erediens en die kerk af nie.

- Hoewel die erediens vir almal, selfs vir ongelowiges en buitestanders, verstaanbaar moet wees, mag dit nie maar bloot 'n gewone menslike byeenkoms wees nie. Uiteindelik moet almal kan aanvoel en bely: "Waarlik, God is hier by julle." Dit is die wesenlike van die erediens. Die atmosfeer moet spreek van God se teenwoodigheid en die aanbidders in sy teenwoordigheid bring.

- Hoewel die erediens 'n korporatiewe byeenkoms is, moet die atmosfeer elke individuele aanbidder tot selfontbloting bring wat oorgaan in ware aanbidding en belydenis.

\section{1 Korintiërs 14:26-40 - orde in die erediens}

In 1 Korintiërs 14:26-40 handel Paulus oor die orde in die erediens. Wanneer die gemeente vergader, kom elkeen daarheen met sy besondere genadegawe (1 Kor. 12:7-10) en wil hy dit ook in beoefening bring (Witherington, 1995:285). Hierteen is geen beswaar nie, maar daar moet gewaak word dat dit nie aanleiding gee tot 'n wanordelike byeenkoms nie. Daarom moet die regulerende beginsel steeds wees dat alles ordelik sal geskied tot opbou van die gemeente. Oorkoepelend staan die liefde wat alle handelinge moet beheer (vgl. 1 Kor. 12:31) en elkeen moet bewaar van liefdelose handelinge selfs wanneer hy ' $n$ genadegawe van die Gees beoefen. Wanneer individuele lede van die gemeente hulle gawes tot voordeel (1 Kor. 12:7), gelyke sorg vir mekaar (1 Kor. 12:25) en tot opbou (1 Kor. 14:2 e.v.) gebruik, is daar vrede.

Wanneer Paulus sê dat alles in die erediens "welvoeglik"1 (1 Kor. 14:40) moet verloop, verwys hy na dit wat hy in 1 Korintiërs 13:5 van die liefde gesê het: die liefde handel nie onwelvoeglik nie. Welvoeglik beteken om mekaar in liefde "in ag te neem", op so 'n wyse dat die swakker lede beleef dat die sterker lede na hulle omsien en op 'n liefdevolle wyse vir hulle sorg. Met ordelik word die gemeente aangemoedig om in die erediens só te funksioneer dat

1 Die 1933/1953-vertaling gebruik die woord welvoeglik. Die 1983/1992-vertaling gebruik gepas. Die Griekse woord eu j́ ch monw staan teenoor a sं chmonew'wat in 1 Korintiërs 13:5 as onwelvoeglik vertaal is in albei vertalings. 
elke lid in harmonie met die ander 'n plek beklee en 'n funksie vervul en dat selfbeheersing en inagneming van mekaar nie geskaad word nie (Martin, 1984:83). God is 'n God van "vrede" (1 Kor. 14:33) en daarom moet die erediens nie net van orde spreek nie, maar van vredevolle orde, van orde in harmonie. In alle besluite moet die maatstaf wees dat die erediens in die geheel en elke bepaalde onderdeel daarvan die opbou van die liggaam bevorder. Ordelikheid het boweal met die goeie funksionering van elke erediensdeelnemer in die liggaam van Christus te doen. Die ordelikheidsbeginsel staan baie sterk wat betref die inagneming van mekaar teenoor oorheersing van mekaar.

Dit is belangrik om daarop te let dat Paulus nie 'n vasgestelde volgorde daarstel of selfs impliseer nie - inteendeel, hy laat ruimte vir verskillende gawes om in verskillende volgordes en selfs met verskillende omvang gebruik te word (1 Kor. 14:26-31). Daar moet selfs ruimte wees vir spontane deelname sonder voorafbeplanning (1 Kor. 14:30). Tog moet daar nie eensydige klem op sekere handelinge wees nie (vergelyk "twee of hoogstens drie" (1 Kor. $14: 27)$ oor die praat in tale en "twee of drie" oor die profesie).

\subsection{Gevolgtrekking}

Die volgende afleidings kan uit 1 Korintiërs 14:26-40 gemaak word:

- Die erediens het die opbou van die gemeente ten doel en daarom moet na die gawes wat die opbou van die gemeente dien, veral die gawe van profesie, gestreef word.

- Wanneer die gemeente in die erediens saamkom, het elkeen 'n bydrae om te lewer, volgens die gawes wat aan hom/haar gegee is. Daarom moet die atmosfeer dit aanmoedig en moontlik maak.

- Daar mag nie 'n atmosfeer heers wat sekere gawes bo ander bevoordeel nie. Ruimte moet geskep word vir die volle werking van die Heilige Gees.

- Die erediens moet ordelik verloop en alles wat gebeur moet gepas en ordelik wees. Dit impliseer 'n atmosfeer van kalmte, beheerstheid en beplanning.

- Hierdie orde is geklee in vrede en harmonie. Daarom is dit belangrik dat daar nie 'n geforseerde, vreeswekkende orde sal heers nie, maar orde in 'n atmosfeer van vrede en harmonie. 


\section{Afleidings uit 1 Korintiërs 11-14}

Uit 1 Korintiërs 11-14 kan die volgende afleidings in verband met atmosfeer in die erediens gemaak word:

- In die erediens is God teenwoordig. Daarom moet die atmosfeer ook God se teenwoordigheid openbaar. Dit beteken dat die erediens nie bloot 'n gewone menslike byeenkoms is nie en dit mag ook nie sodanig ingerig word nie. Die atmosfeer moet een van heiligheid en gewydheid wees.

- Tog is dit duidelik dat die erediens nie in 'n onverstaanbare mistiek mag verval waar die dinge wat in die erediens gebeur vreemd en intimiderend vir buitestanders en ongelowiges is nie. Die atmosfeer moet dus sodanig wees dat vreemdelinge tuis en welkom voel en nadergetrek word. Dit impliseer warmte, vriendelikheid en veral liefde. Liefde is die belangrikste eienskap van die erediens.

- Hoewel dit in die erediens oor die aanbidding van die ewige, onveranderlike God gaan, moet die erediens sover moontlik by die algemeen aanvaarde samelewingsnorme en -gebruike aanpas en mag dit nie werklikheidsvreemd wees nie.

- In die erediens moet ruimte geskep word om die verskillende gawes te kan gebruik, soms selfs spontaan, wat beteken dat die atmosfeer dit moet toelaat en aanmoedig. Dit beteken ' $n$ atmosfeer waar mense tuis voel en gemaklik is.

- Hoewel die erediens ruimte moet skep vir verskeidenheid en die gebruik van verskillende gawes, moet alles ordelik geskied. Hierdie orde gaan met harmonie gepaard en daarom moet ' $n$ atmosfeer van vrede in die erediens heers.

- Tog moet die erediens nie net verskeidenheid erken en bemagtig nie, maar ook die eenheid beklemtoon en verstewig. Dit is belangrik dat die atmosfeer in die erediens versoenend en samebindend en nie verdelend en skeidend is nie.

- Die erediens het gevolglik 'n belangrike pastorale dimensie waar die atmosfeer onderlinge sorg, opbou, bemoediging en vertroosting moet fasiliteer.

- Simbole en simboliese handelinge is belangrik in die erediens, omdat dit nie net 'n boodskap oorbring nie, maar ook atmosfeer skep. Hierdie atmosfeer moet verenigend en uitnodigend wees en nie skeiding bring nie. 
- Omdat die erediens in sy wese 'n ontmoeting met God is, is dit belangrik dat die atmosfeer die gemeente se gedagtes op God en nie op mense nie moet rig en fokus. Aanbidding in die erediens moet tot eer van God geskied, anders ontaard die erediens in mensbewondering en in jaloesie op die verskillende gawes in plaas daarvan om 'n ontmoeting te wees met God wat dit alles gegee het.

- Omdat kennis maar ten dele is, sal 'n erediens nooit volmaak wees nie. Daarom moet die atmosfeer kreatiewe deelname en denke stimuleer en ruimte maak vir innovasie ten einde nader te kom aan die toekomstige volmaaktheid.

- Dit is belangrik dat alles in die gemeente verstaanbaar is - selfs vir die ongelowige of die onvolwasse (geestelik en/of ouderdom!) gelowige. Die atmosfeer moet juis sulke mense nader trek en omarm, sodat hulle ook daartoe kan kom om die Here te ontmoet. Daarom juis mag die erediens húlle nooit verveel, intimideer of wegdryf nie.

- Die atmosfeer in die erediens is nie eenvormig deur die verloop van die erediens nie. Daar moet geleenthede wees waar die atmosfeer die teenwoordiges aanspreek, geleenthede waar hulle op hulle knieë in aanbidding gedwing word, geleenthede waar hulle hulle harte verhef in lofprysing, geleenthede waar hulle onderrig word, geleenthede waar hulle tot belydenis aangevuur word, en so meer. 'n Verskeidenheid momente vereis telkens 'n verskillende atmosfeer.

\section{Basisteoretiese beginsels uit 1 Korintiërs 11-14}

$\mathrm{Na}$ aanleiding van 1 Korintiërs 11-14 kan die volgende basisteoretiese beginsels oor die atmosfeer in die erediens gemaak word:

- Dit is belangrik dat die aanbidder in die erediens God se teenwoordigheid ervaar, op Hom fokus en Hom ontmoet.

- In die erediens moet almal (gelowiges en ongelowiges) welkom en tuis voel. Die erediens moet almal uitnooi en nader trek om uiteindelik in God se teenwoordigheid te wees.

- Die erediens moet ruimte skep vir elke aanbidder om deel te neem volgens die gawes wat die Heilige Gees vir hom/haar gegee het. 
- Alle teenwoordiges moet die eenheid met God en met mekaar ervaar. Hierdie eenheid word veral in 'n atmosfeer van liefde gekonkretiseer.

- 'n Atmosfeer van vreedsame orde moet in die erediens heers waarin die dinge wat gebeur sinvol en verstaanbaar is.

- Die aanbidders moet ook pastoraal versterk, ondersteun en gebou word.

- In die erediens moet die mens in sy totaliteit betrek word. Dit sluit ook die meer kreatiewe en emosionele kante van 'n persoon in.

\section{Geraadpleegde bronne}

BARNARD, A.C. 1980. Die teenwoordigheid van Christus in die erediens. Pretoria: Universiteit van Pretoria.

BERKHOF, H. 1973. Christelijk geloof. Nijkerk: Callenbach.

BREYTENBACH, H.S. \& PIETERSE, H.J.C. 1992. Doelwitte vir gemeentebou in die lig van 'n praktiese-teologiese ekklesiologie. Praktiese teologie in Suid-Afrika, 7(2):101-112.

CARSON, D.A. 1987. Showing the Spirit: a theological exposition of 1 Corinthians 12-14. Grand Rapids: Baker.

DE KLERK, B.J. 1987. Die Heilige Gees in die verhouding Skriflesing, prediking en gebed in die erediens. Potchefstroom: PU vir CHO. (Th.D.-proefskrif.)

DU PLOOY, A. LE R. 1998. Inleiding op die kerkorde van die Gereformeerde Kerke in Suid-Afrika. (In GKSA. Kerkordeboekie van die Gereformeerde Kerke in Suid-Afrika. Potchefstroom: GKSA. p. 1-11.)

DU RAND, J.A. 1993. 1 Korintiërs. (In Vosloo, W. \& Van Rensburg, F., reds. Die Bybel in praktyk. Vereeniging: Christelike Uitgewersmaatskappy.) (Logos Bybelbiblioteek Vlak 3.) [CD-ROM.]

GROENEWALD, E.P. 1967. Die eerste brief aan die Korinthiërs. Kaapstad: Lux Verbi. (Lux Verbi Versameling vir Logos-rekenaarprogram.) [CD-ROM.]

HORSLEY, R.A. 1998. Abingdon New Testament commentaries: 1 Corinthians. Nashville: Abingdon.

LENSKI, R.C.H. 1963. The interpretation of St. Paul's first and second Epistles to the Corinthians. Minneapolis: Augsburg.

LLOYD-JONES, D.M. 1974. Life in the Spirit in marriage, home and work. Grand Rapids: Baker.

LOUW, J.P. \& NIDA, E.A. 1989. Greek-English lexicon of the New Testament based on semantic domains. New York: United Bible Societies.

MARTIN, R.P. 1984. The Spirit and the congregation: studies in 1 Corinthians 12-15. Grand Rapid: Eerdmans.

NEL, M. 1994. Gemeentebou. Halfway House: Orion.

POSTMA, J. 1993. 1 Korintiërs. (In Van Zyl, A.H., red. Die Bybel verklaar: 1983vertaling. Kaapstad: Lux Verbi.BM.) (Logos Bybelbiblioteek Vlak 3.) [CDROM.]

QUAST, K. 1994. Reading the Corinthian correspondence: an introduction. New York: Paulist. 
ROBERTS, J.H. 1988. Die kerk by Paulus. (In Du Toit, A.B., red. Handleiding by die Nuwe Testament. Band V. Pretoria: N.G. Kerkboekhandel. p. 282231.)

SOARDS, M.L. 1999. 1 Corinthians: new international Bible commentary. Peabody: Hendrickson.

THISTELTON, A.C. 2000. The first Epistle to the Corinthians: a commentary on the Greek text. Grand Rapids: Eerdmans. (The new international Greek Testament commentary.)

WITHERINGTON, B. 1995. Conflict and community in Corinthians: a sociorhetorical commentary on 1 and 2 Corinthians. Grand Rapids: Eerdmans.

WOLMARANS, J.L.P. 1999. 1 Korintiërs. (In Vosloo, W. \& Van Rensburg, F.J., reds. Die Bybellennium eenvolumekommentaar. Vereeniging: Christelike Uitgewersmaatskappy. p. 1492-1525.)

ZERFASS, R. 1974. Praktische Teologie als Handelungswissenschaft. (In Klostermann, F. \& Zerfass, R. Praktische Teologie Heute. München: Kaiser. S. 164-177.)

\section{Kernbegrippe:}

\section{Korintiërs 11-14}

atmosfeer: die belewenis binne die erediens

erediens: samekoms van gelowiges

liturgie:handelinge binne die erediens

\section{Key concepts:}

\section{Corinthians 11-14}

atmosphere: the experience in the worship service

liturgy: acts in the worship service

worship service: gathering of believers 
